Proofs to: Dr. George Britovsek

Department of Chemistry

Imperial College London

Exhibition Road

South Kensington

London SW7 2AY

UK

Tel. +44-(0)20-75945863

e-mail: g.britovsek@imperial.ac.uk

\title{
Towards Photocatalytic Alkane Oxidation: The Insertion of Dioxygen into a Platinum(II) Methyl Bond
}

Russell A. Taylor ${ }^{\mathrm{a}}$, David J. Law ${ }^{\mathrm{b}}$, Glenn J. Sunley ${ }^{\mathrm{b}}$, Andrew J.P. White ${ }^{\mathrm{a}}$ and George J.P. Britovsek $^{\mathrm{a} *}$,

a) Department of Chemistry, Imperial College London, Exhibition Road, London, SW7 $2 A Y, U K$.

b) Hull Research and Technology Centre, BP Chemicals Ltd., Saltend, Hull, HU12 8DS, $U K$

Keywords: singlet oxygen, platinum, photosensitiser, alkane oxidation 
The selective catalytic oxidation of methane and higher alkanes remains one of the great challenges in catalysis research. Considerable progress has been made during the last three decades regarding the $\mathrm{C}-\mathrm{H}$ activation of alkanes, in particular electrophilic activation reactions with late transition metals. ${ }^{[1-4]}$ Once C-H bond cleavage has occurred at a metal centre, a functionalisation of the metal carbon bond is required, followed by release of the product and regeneration of the catalyst. In the case of oxidation reactions, this functionalisation of metal alkyl complexes should be carried out ideally with environmentally benign oxidants such as $\mathrm{O}_{2}$ or $\mathrm{H}_{2} \mathrm{O}_{2}$. In a previous study, we reported the oxidation of dimethyl $\mathrm{Pt}^{\mathrm{II}}$ complexes with $\mathrm{H}_{2} \mathrm{O}_{2}$ to generate cis-dihydroxo $\mathrm{Pt}^{\mathrm{IV}}$ complexes. $^{[5]}$ The unusual cis isomer was obtained by using amino-substituted bipyridine ligands, which stabilise this isomer through hydrogen bonding. When we extended our work to $\mathrm{Pt}^{\mathrm{II}}$ methyl complexes containing tridentate amino-substituted terpyridine ligands, we discovered a remarkable reactivity of the diamino substituted terpy $\mathrm{Pt}^{\mathrm{II}}$ methyl complex towards $\mathrm{O}_{2}$.

The reaction of 6,6'-diaminoterpyridine (1) with $\left[\mathrm{Pt}\left(\mathrm{SMe}_{2}\right)_{2} \mathrm{MeCl}\right]$, followed by reaction with $\mathrm{AgSbF}_{6}$, affords the ionic complex $[\mathrm{Pt}(\mathbf{1}) \mathrm{Me}]\left[\mathrm{SbF}_{6}\right]$. When dioxygen is passed through a solution of $[\mathrm{Pt}(\mathbf{1}) \mathrm{Me}]\left[\mathrm{SbF}_{6}\right]$ in a polar solvent such as acetonitrile or acetone at room temperature and in ambient light, a reaction takes place. In the ${ }^{1} \mathrm{H}$ NMR spectrum, the characteristic Pt-Me signal at $1.54 \mathrm{ppm}\left(J_{\mathrm{Pt}-\mathrm{H}}=72 \mathrm{~Hz}, \mathrm{~d}_{6}\right.$-acetone $)$ disappears over the course of several minutes and a new singlet emerges at $3.39 \mathrm{ppm}\left(\mathrm{d}_{6^{-}}\right.$ acetone), together with a new set of signals for the 6,6'-diaminoterpyridine ligand (see Figures S1 and S3). This new complex was isolated in quantitative yield and all analytical data suggest that an insertion of $\mathrm{O}_{2}$ into the Pt-methyl bond has occurred to form a methylperoxo complex $[\mathrm{Pt}(\mathbf{1}) \mathrm{OOMe}]\left[\mathrm{SbF}_{6}\right]$ (Eq. 1). The rate of the $\mathrm{O}_{2}$ insertion reaction is affected by light. Whereas the reaction proceeds within several minutes at room temperature in ambient light, in the absence of light the reaction is very slow and only $50 \%$ conversion is obtained after 13 hours at room temperature. 

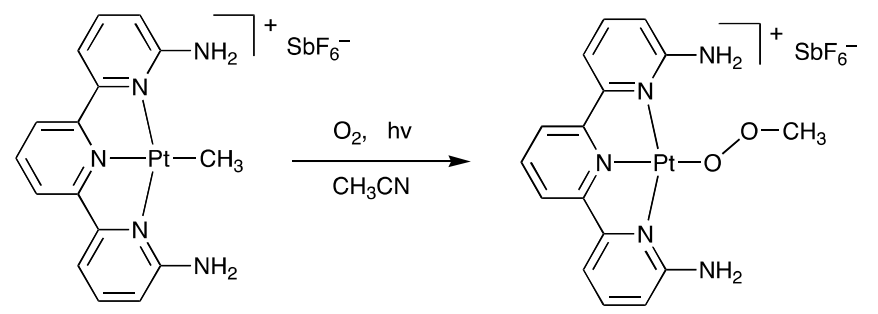

The solid state structure of $[\mathrm{Pt}(\mathbf{1}) \mathrm{OOMe}]\left[\mathrm{SbF}_{6}\right]$ shows the presence of two crystallographically independent cation:anion pairs with the two unique cations forming a

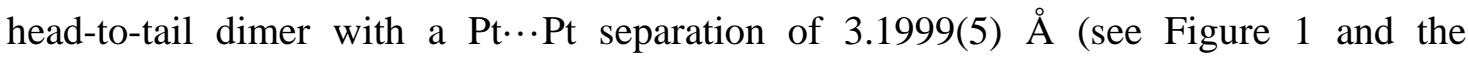
supporting material for further information). ${ }^{[6]}$ This dimer formation is quite common for terpy $\mathrm{Pt}^{\mathrm{II}}$ complexes and arises from metal-metal and $\pi-\pi$ interactions. ${ }^{[7]}$ It is for example also observed in the solid state structure of [Pt(terpy)Me][BPh 4$]$ (mean plane separation of $3.42 \AA){ }^{[8]}$

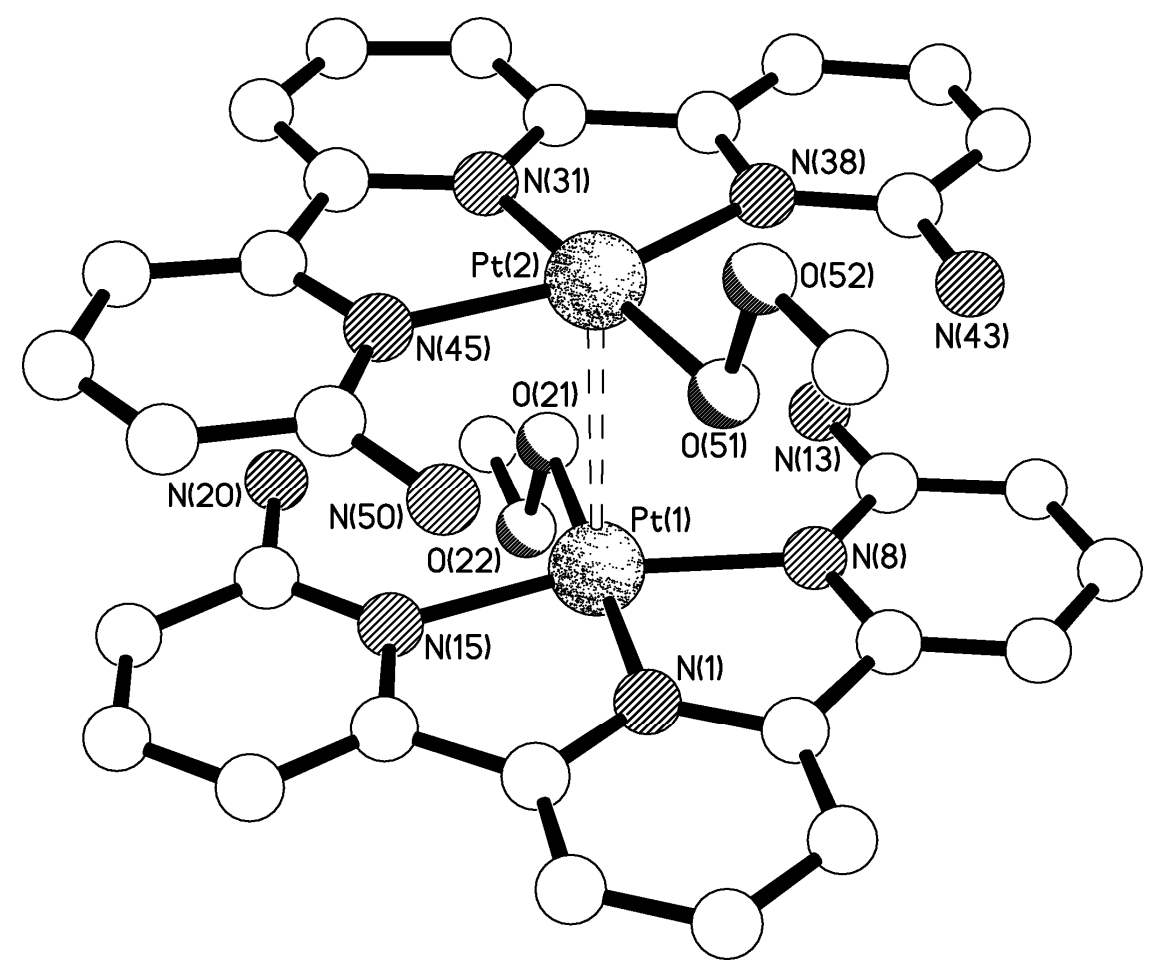

Figure 1. The molecular structure of the cation dimer present in the crystals of [Pt(1)OOMe][SbF$]_{6} .^{[6]}$ 
In the solid state and in solution, $\mathrm{NH} \cdots \mathrm{O}$ hydrogen bonding interactions exist between the amino substituents and the $\alpha-\mathrm{O}$ atom (see Supplementary Material). The amino substituents have also a marked effect on the electronic properties, which is illustrated by the UV-vis spectra of $[\mathrm{Pt}(\mathbf{1}) \mathrm{Me}]\left[\mathrm{SbF}_{6}\right]$ and $[\mathrm{Pt}(\mathrm{terpy}) \mathrm{Me}]\left[\mathrm{SbF}_{6}\right]$ in Figure 2. The extinction coefficient $(\varepsilon)$ for the absorption in the MLCT region between 350 and $450 \mathrm{~nm}$ is an order of magnitude greater for the diamino-substituted complex. Preliminary studies have shown that complex $[\mathrm{Pt}(\mathbf{1}) \mathrm{Me}]\left[\mathrm{SbF}_{6}\right]$ shows photoluminescence in $\mathrm{CH}_{2} \mathrm{Cl}_{2}$ solution at room temperature, similar to observations with other substituted terpyridine $\mathrm{Pt}^{\mathrm{II}}$ complexes. ${ }^{[9-11]}$ Excitation of the charge transfer region at $388 \mathrm{~nm}$ results in an emission spectrum with maxima at 580 and $654 \mathrm{~nm}$ (see Supplementary Information). Noteworthy, the diamino substituted terpyridine ligand itself also shows photoluminescence. ${ }^{[12,13]}$ The luminescent behaviour of $[\operatorname{Pt}(\mathbf{1}) \mathrm{Me}]^{+}$is very different from $[\mathrm{Pt}(\text { terpy }) \mathrm{Me}]^{+}$, which shows no significant photoluminescence at room temperature in $\mathrm{CH}_{3} \mathrm{CN}{ }^{[8]}$

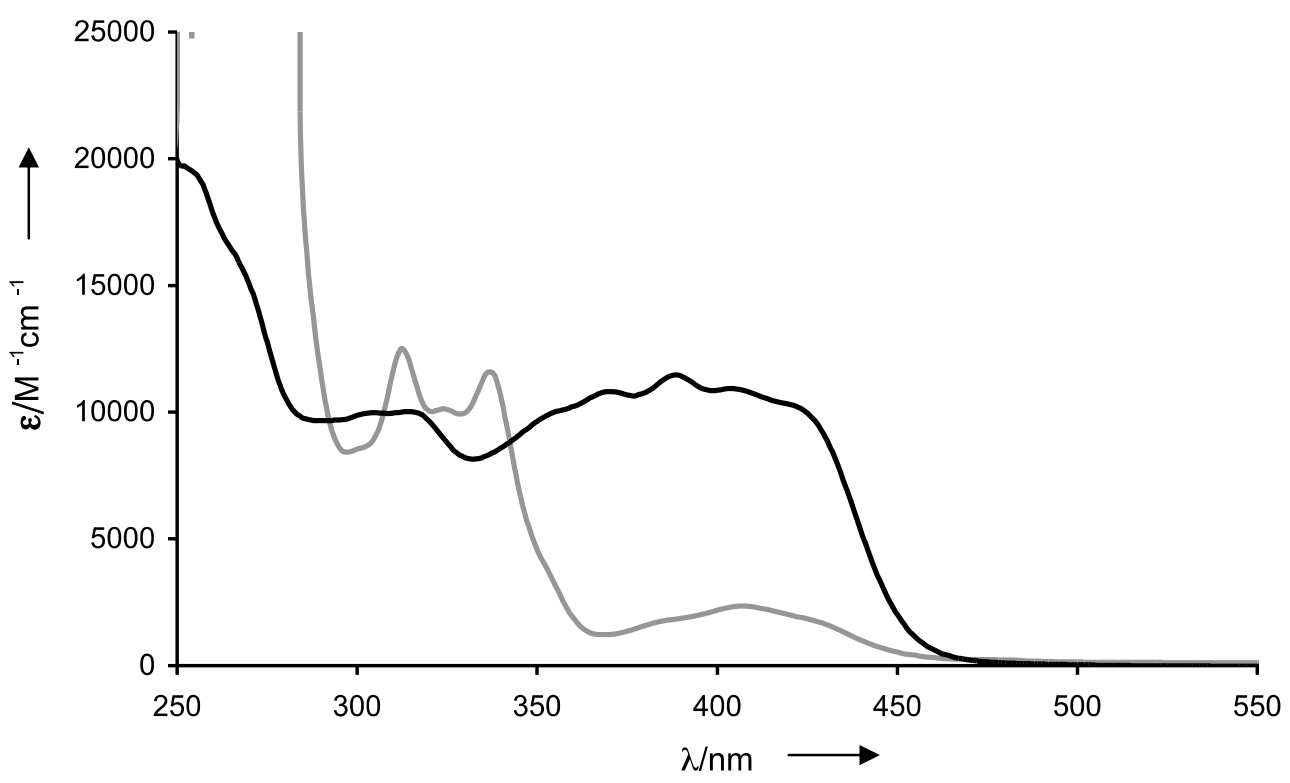

Figure 2. UV-vis spectra for $[\mathrm{Pt}(\mathbf{1}) \mathrm{Me}]\left[\mathrm{SbF}_{6}\right]$ (black) and $\left[\mathrm{Pt}(\right.$ terpy)Me $]\left[\mathrm{SbF}_{6}\right]$ (grey) in $\mathrm{CH}_{3} \mathrm{CN}$ at $298 \mathrm{~K}$. 
The formation of a methylperoxo $\mathrm{Pt}^{\mathrm{II}}$ complex via insertion of $\mathrm{O}_{2}$ into a $\mathrm{Pt}^{\mathrm{II}}$ methyl bond as seen here, appears to be very rare. The only other example is a recently reported complex $[(\mathrm{PN}) \mathrm{Pt}(\mathrm{Me})(\mathrm{OOMe})]$ by Grice and Goldberg $(\mathrm{PN}=2$-bis $($ tertbutylphosphinomethyl)pyridine). ${ }^{[14]}$ In addition, several $\mathrm{Pt}^{\mathrm{II}}$ and $\mathrm{Pt}^{\mathrm{IV}}$ complexes containing alkylperoxo ligands other than methylperoxo have been reported previously, but none of these have been prepared via an $\mathrm{O}_{2}$ insertion reaction. ${ }^{[15-20]}$ The $\mathrm{O}_{2}$ insertion reaction into the $\mathrm{Pt}^{\mathrm{II}}-\mathrm{Me}$ bond in the complex $[(\mathrm{PN}) \mathrm{Pt}(\mathrm{Me})(\mathrm{OOMe})]$ is also affected by light and the authors have proposed a radical mechanism for their insertion reaction. ${ }^{[14]}$ Similarly, the insertion of $\mathrm{O}_{2}$ into a $\mathrm{Pt}^{\mathrm{IV}}-\mathrm{H}$ bond has been reported to involve a radical pathway, ${ }^{[21]}$ and insertions of $\mathrm{O}_{2}$ into other transition metal methyl bonds such as Co and Fe methyl complexes proceed via methyl radicals. ${ }^{[22,23]}$ In contrast, two reports on the direct insertion of $\mathrm{O}_{2}$ into $\mathrm{Pd}^{\mathrm{II}}-\mathrm{H}$ bonds have shown that these insertion reactions are not affected by light. ${ }^{[24,25]}$ Mechanistic investigations suggest that these reactions proceed by a $\mathrm{Pd} / \mathrm{HO}_{2}$ (triplet) radical pair intermediate or via a stepwise pathway initiated by reductive elimination of $\mathrm{HX}$ to form an $\mathrm{O}_{2}$-reactive $\mathrm{Pd}^{0}$ intermediate. ${ }^{\text {[26, 27] }}$

Dioxygen, in its triplet ground state, is rather unreactive because reactions are spinforbidden and require a triplet-singlet surface crossing on the reaction coordinate. ${ }^{\text {[28] }}$ Many organic $\mathrm{O}_{2}$ sensitizers such as rose bengal or methylene blue are able to convert triplet oxygen $\left({ }^{3} \mathrm{O}_{2}\right)$ into singlet oxygen $\left({ }^{1} \mathrm{O}_{2}\right),{ }^{[29]}$ but also certain $\mathrm{Pt}^{\mathrm{II}}$ and $\mathrm{Ir}^{\mathrm{III}}$ complexes are known to be able to act as $\mathrm{O}_{2}$ sensitizers and generate ${ }^{1} \mathrm{O}_{2} \cdot{ }^{[30-32]}$ In some cases, in situ generated ${ }^{1} \mathrm{O}_{2}$ can react with organometallic complexes, for example to generate peroxide complexes. $^{[33,34]}$ Examples of self-sensitisation, whereby a metal complexes can both generate ${ }^{1} \mathrm{O}_{2}$ and react with ${ }^{1} \mathrm{O}_{2}$, are relatively rare but have been observed for certain $\mathrm{Pt}^{\mathrm{II}}$ bipy dithiolate complexes. ${ }^{[35,36]}$ The electronic spectra and luminescent properties of [Pt(1)Me] $\left[\mathrm{SbF}_{6}\right]$ are strong indicators that this complex can act as an $\mathrm{O}_{2}$ sensitizer and we therefore propose a non-radical mechanism for the insertion of $\mathrm{O}_{2}$ in the case of complex [Pt(1)Me][SbF 6 , which we believe proceeds via initial ${ }^{3} \mathrm{O}_{2}$ sensitization by this complex to generate ${ }^{1} \mathrm{O}_{2}$, followed by a fast ${ }^{1} \mathrm{O}_{2}$ insertion into the Pt methyl bond. The difference between the two mechanisms is illustrated by the fact that the $\mathrm{O}_{2}$ insertion reaction reported by Grice and Goldberg provides the methylperoxo complex in 64-79\% yield at 5 atm $\mathrm{O}_{2}$ pressure after $7-11$ hours, ${ }^{[14]}$ whereas in our case the insertion reaction proceeds 
quantitatively at $1 \mathrm{~atm} \mathrm{O}_{2}$ within minutes. In the case of complex $[\mathrm{Pt}(\mathbf{1}) \mathrm{Cl}]\left[\mathrm{SbF}_{6}\right]$, which cannot insert $\mathrm{O}_{2}$, the formation of ${ }^{1} \mathrm{O}_{2}$ was confirmed by the oxidation of 2,2,6,6tetramethylpiperidine (TMP) with $\mathrm{O}_{2}$, in the presence of $[\mathrm{Pt}(\mathbf{1}) \mathrm{Cl}]\left[\mathrm{SbF}_{6}\right]$ and light. ${ }^{[31,37 \text {, }}$ 38] The reaction product, TEMPO, is a stable radical, which can be detected by EPR (see Supplementary Information).

Singlet oxygen is similar in character to an electron-deficient alkene and metal complexes containing a coordinated ${ }^{1} \mathrm{O}_{2}$ ligand have recently been reported. ${ }^{[39,40]}$ Coordination prior to insertion, akin to alkene insertions into a metal alkyl bond, to give an intermediate $\mathrm{Pt}^{\mathrm{II}}$ complex containing an $\eta^{2}$-bound ${ }^{1} \mathrm{O}_{2}$ ligand cannot be excluded at this stage, although we have not observed any intermediates by NMR at room temperature. In contrast to the reactivity of $[\mathrm{Pt}(\mathbf{1}) \mathrm{Me}]\left[\mathrm{SbF}_{6}\right]$ with $\mathrm{O}_{2}$, the reaction of [Pt(terpy)Me] $\left[\mathrm{SbF}_{6}\right]$ with $\mathrm{O}_{2}$ in either acetone or acetonitrile, under identical conditions (ambient light and room temperature), does not result in an insertion reaction. The UVvis spectra in Figure 2 show a distinctly different charge transfer behaviour between these two complexes and it has been previously reported ${ }^{[8]}$ that $\left[\mathrm{Pt}(\text { terpy)Me }]^{+}\right.$complexes are non-emissive and therefore this complex is not able to act as a photosensitizer and generate ${ }^{1} \mathrm{O}_{2}$.

The reaction between $[\mathrm{Pt}(\mathbf{1}) \mathrm{Me}]\left[\mathrm{SbF}_{6}\right]$ and $\mathrm{O}_{2}$ can be monitored by ${ }^{1} \mathrm{H}$ NMR spectroscopy and the quantitative formation of complex $[\mathrm{Pt}(\mathbf{1}) \mathrm{OOMe}]\left[\mathrm{SbF}_{6}\right]$ typically occurs at room temperature within 2-3 minutes upon exposure to ambient light. The product can be isolated and is stable for days at $-20{ }^{\circ} \mathrm{C}$ in the absence of light. However, prolonged exposure ( $>5 \mathrm{~min}$.) of the methyl peroxo complex [Pt(1)OOMe][SbF 6$]$ to light at room temperature results in a further reaction. This reaction was monitored by ${ }^{1} \mathrm{H}$ NMR and the disappearance of $[\mathrm{Pt}(\mathbf{1}) \mathrm{OOMe}]\left[\mathrm{SbF}_{6}\right]$ and the formation of $[\operatorname{Pt}(\mathbf{1}) \mathrm{OH}]\left[\mathrm{SbF}_{6}\right]\left(\delta=0.62 \mathrm{ppm}\right.$ broad, $\mathrm{d}_{6}$-acetone $)$ and formaldehyde $\left(\delta=9.67 \mathrm{ppm}, \mathrm{d}_{6^{-}}\right.$ acetone) are observed (see eq. 2 and Figure S2 in the Supporting Information). The formation of the hydroxo $\mathrm{Pt}^{\mathrm{II}}$ complex was confirmed by the independent preparation from $[\mathrm{Pt}(\mathbf{1}) \mathrm{Cl}]^{+}$and $\mathrm{NaOH}$. This decomposition pathway of a methylperoxo complex has also been observed in the decomposition of FeOOMe complexes. ${ }^{[22,23]}$ We propose that this reaction proceeds via an initial $\eta^{2}$-alkylperoxo intermediate, which after oxidative 
addition of the $\mathrm{O}-\mathrm{O}$ bond results in a $\mathrm{Pt}^{\mathrm{IV}}=\mathrm{O}(\mathrm{OMe})$ intermediate. The recently reported $\mathrm{Pt}^{\mathrm{IV}}$ complex with a terminal oxo ligand by Milstein and co-workers supports the existence of such an intermediate. ${ }^{[41]}$ This rearrangement has precedent in the reaction of the methylperoxo $\mathrm{Ta}^{\mathrm{III}}$ complex $\left[\left(\mathrm{Cp}^{*}\right)_{2} \mathrm{Ta}\left(\eta^{2}-\mathrm{OOMe}\right)\right]$, which can rearrange to $\left[\left(\mathrm{Cp}^{*}\right)_{2} \mathrm{Ta}^{\mathrm{V}}=\mathrm{O}(\mathrm{OMe})\right]$ as shown by Bercaw and co-workers. ${ }^{[42]}$ In our case, the subsequent hydrogen abstraction results in the formation of $[\mathrm{Pt}(\mathbf{1}) \mathrm{OH}]\left[\mathrm{SbF}_{6}\right]$ and formaldehyde. This process is probably also related to the $\mathrm{O}_{2}$ insertion reaction into a $\mathrm{Cr}^{\mathrm{II}}$ phenyl bond reported by Theopold and co-workers, which results in the formation of a $\mathrm{Cr}^{\mathrm{IV}}=\mathrm{O}(\mathrm{OPh})$ complex. ${ }^{[43]}$

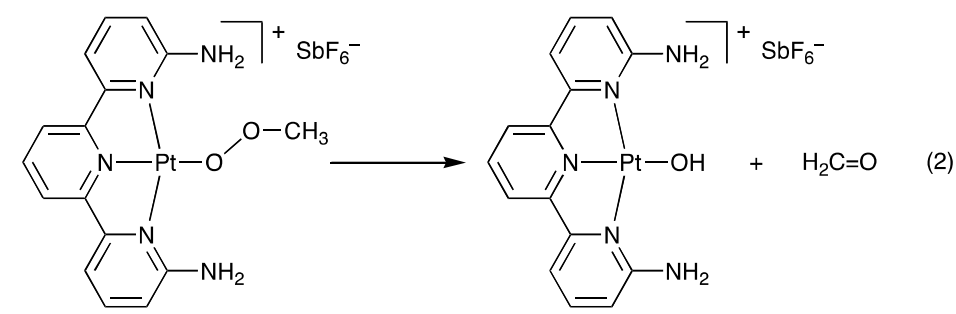

In conclusion, we have shown that a diaminoterpyridine substituted $\mathrm{Pt}^{\mathrm{II}}$ methyl complex can insert $\mathrm{O}_{2}$ to form a methylperoxo complex and that this reaction proceeds via the formation of singlet oxygen. The methylperoxo $\mathrm{Pt}^{\mathrm{II}}$ complex eliminates formaldehyde and forms a $\mathrm{Pt}^{\mathrm{II}}$ hydroxo complex. If this $\mathrm{Pt}^{\mathrm{II}}$ hydroxo complex could be re-converted to a $\mathrm{Pt}^{\mathrm{II}}$ methyl complex, the exciting prospect arises for a direct lowtemperature photocatalytic oxidation of methane to formaldehyde. Recent examples of C-H activation with late-transition metal hydroxo complexes suggest that this may not be impossible. ${ }^{[44,45]}$

Acknowledgements. We are grateful to BP Chemicals Ltd. and EPSRC for a CASE award for R.T. and to Johnson Matthey for a generous loan of Pt salts. Mr Peter Haycock and Mr Dick Sheppard are thanked for NMR measurements and Mr Hugo Bronstein for his assistance with emission spectroscopy studies. Dr Steve Rigby (Queen Mary University, London) is thanked for EPR measurements. G.B. thanks Prof. Gerhard Erker 
and the International Research Training Group (IRTG) for a Visiting Lectureship at the University of Münster in Germany during the writing of this paper.

\section{References}

[1] R. H. Crabtree, J. Chem. Soc. Dalton Trans. 2001, 2437.

[2] S. S. Stahl, J. A. Labinger, J. E. Bercaw, Angew. Chem. Int. Ed. Engl. 1998, 37, 2180.

[3] U. Fekl, K. I. Goldberg, Adv. Inorg. Chem. 2003, 54, 259.

[4] M. Lersch, M. Tilset, Chem. Rev. 2005, 105, 2471.

[5] R. A. Taylor, D. J. Law, G. J. Sunley, A. J. P. White, G. J. P. Britovsek, Chem. Commun. 2008, 2800.

[6] Crystal data for $[\mathrm{Pt}(\mathbf{1}) \mathrm{OOMe}]\left[\mathrm{SbF}_{6}\right]:\left[\mathrm{C}_{16} \mathrm{H}_{16} \mathrm{~N}_{5} \mathrm{O}_{2} \mathrm{Pt}\right]\left(\mathrm{SbF}_{6}\right), M=741.18$, triclinic, $\boldsymbol{P} \overline{\mathbf{1}}$ (no. 2), $a=11.9822(7), b=13.1681(13), c=13.7797(14) \AA, \alpha=$ 76.641(9), $\beta=80.491(6), \gamma=72.974(7)^{\circ}, V=2011.5(3) \AA^{3}, Z=4$ [2 independent molecules], $\rho_{\text {calcd }}=2.447 \mathrm{~g} \mathrm{~cm}^{-3}, \mu\left(\mathrm{Mo}_{\mathrm{K} \alpha}\right)=8.369 \mathrm{~mm}^{-1}, T=173 \mathrm{~K}$, orange needles, Oxford Diffraction Xcalibur 3 diffractometer; 12981 independent measured reflections, $F^{2}$ refinement, $R_{1}=0.043, w R_{2}=0.104,10111$ independent observed absorption-corrected reflections $\left[\left|F_{\mathrm{o}}\right|>4 \sigma\left(\left|F_{\mathrm{o}}\right|\right), 2 \theta_{\max }=65^{\circ}\right], 701$ parameters. CCDC 699504 contains the supplementary crystallographic data for this paper. These data can be obtained free of charge from the Cambridge Crystallographic Data Centre via www.ccdc.cam.ac.uk/data_request/cif.

[7] J. A. Bailey, M. G. Hill, R. E. Marsh, V. M. Miskowski, W. P. Schaefer, H. B. Gray, Inorg. Chem. 1995, 34, 4591.

[8] R. Romeo, L. M. Scolaro, M. R. Plutino, A. Albinati, J. Organomet. Chem. 2000, 593-594, 403.

[9] T. K. Aldridge, E. M. Stacy, D. R. McMillin, Inorg. Chem. 1994, 33, 722.

[10] S.-W. Lai, M. C. W. Chan, K.-K. Cheung, C.-M. Che, Inorg. Chem. 1999, 38, 4262.

[11] D. R. McMillin, J. J. Moore, Coord. Chem. Rev. 2002, 229, 113.

[12] J.-D. Cheon, T. Mutai, K. Araki, Org. Biomol. Chem. 2007, 5, 2762. 
[13] K. Araki, T. Mutai, Y. Shigemitsu, M. Yamada, T. Nakajima, S. Kuroda, I. Shimao, J. Chem. Soc., Perkin Trans. 2 1996, 613.

[14] K. A. Grice, K. I. Goldberg, Organometallics 2009, 28, 953.

[15] G. Strukul, R. A. Michelin, J. D. Orbell, L. Randaccio, Inorg. Chem. 1983, 22, 3706.

[16] J.-M. Bregeault, H. Mimoun, Nouv. J. Chim. 1981, 5, 287.

[17] O. J. Scherer, H. Jungmann, K. Hussong, J. Organomet. Chem. 1983, 247, C1.

[18] Y. Tatsuno, S. Otsuka, J. Am. Chem. Soc. 1981, 103, 5832.

[19] V. V. Rostovtsev, L. M. Henling, J. A. Labinger, J. E. Bercaw, Inorg. Chem. 2002, 41, 3608.

[20] G. Ferguson, P. K. Monaghan, M. Parvez, R. J. Puddephatt, Organometallics 1985, 4, 1669.

[21] D. D. Wick, K. I. Goldberg, J. Am. Chem. Soc. 1999, 121, 11900.

[22] R. D. Arasasingham, A. L. Balch, C. R. Cornman, L. Latos-Grazynski, J. Am. Chem. Soc. 1989, 111, 4357.

[23] R. D. Arasasingham, A. L. Balch, L. Latos-Grazynski, J. Am. Chem. Soc. 1987, 109, 5846.

[24] M. C. Denney, N. A. Smythe, K. L. Cetto, R. A. Kemp, K. I. Goldberg, J. Am. Chem. Soc. 2006, 128, 2508.

[25] M. M. Konnick, B. A. Gandhi, I. A. Guzei, S. S. Stahl, Angew. Chem. Int. Ed. 2006, 45, 2904.

[26] J. M. Keith, R. P. Muller, R. A. Kemp, K. I. Goldberg, W. A. Goddard III, J. Oxgaard, Inorg. Chem. 2006, 45, 9631.

[27] M. M. Konnick, S. S. Stahl, J. Am. Chem. Soc. 2008, 130, 5753.

[28] C. R. Landis, C. M. Morales, S. S. Stahl, J. Am. Chem. Soc. 2004, 126, 16302.

[29] M. C. DeRosa, R. J. Crutchley, Coord. Chem. Rev. 2002, 233-234, 351.

[30] P. I. Djurovich, D. Murphy, M. E. Thompson, B. Hernandez, R. Gao, P. L. Hunt, M. Selke, Dalton Trans. 2007, 3763.

[31] D. Zhang, L.-Z. Wu, Q.-Z. Yang, X.-H. Li, L.-P. Zhang, C.-H. Tung, Org. Lett. 2003, 5, 3221. 
[32] X.-H. Li, L.-Z. Wu, L.-P. Zhang, C.-H. Tung, C.-M. Che, Chem. Commun. 2001, 2280.

[33] D. G. Ho, R. Ismail, N. Franco, R. Gao, E. P. Leverich, I. Tsyba, N. N. Ho, R. Bau, M. Selke, Chem. Commun. 2002, 570.

[34] M. Selke, C. S. Foote, J. Am. Chem. Soc. 1993, 115, 1166.

[35] W. B. Connick, H. B. Gray, J. Am. Chem. Soc. 1997, 119, 11620.

[36] Y. Zhang, K. D. Ley, K. S. Schanze, Inorg. Chem. 1996, 35, 7102.

[37] K. Feng, R.-Y. Zhang, L.-Z. Wu, B. Tu, M.-L. Peng, L.-P. Zhang, D. Zhao, C.-H. Tung, J. Am. Chem. Soc. 2006, 128, 14685.

[38] Y. Lion, M. Delmelle, A. van de Vorst, Nature 1976, 263, 442.

[39] C. M. Frech, L. J. W. Shimon, D. Milstein, Helv. Chim. Acta 2006, 89, 1730.

[40] J. M. Praetorius, D. P. Allen, R. Wang, J. D. Webb, F. Grein, P. Kennepohl, C. M. Crudden, J. Am. Chem. Soc. 2008, 130, 3724.

[41] E. Poverenov, I. Efremenko, A. I. Frenkel, Y. Ben-David, L. J. W. Shimon, G. Leitus, L. Konstantinovski, J. M. L. Martin, D. Milstein, Nature 2008, 455, 1093.

[42] A. van Asselt, M. S. Trimmer, L. M. Henling, J. E. Bercaw, J. Am. Chem. Soc. 1988, 110, 8254 .

[43] A. Hess, M. A. Horz, L. M. Liable-Sands, D. C. Lindner, A. L. Rheingold, K. H. Theopold, Angew. Chem. Int. Ed. Engl. 1999, 38, 166.

[44] S. M. Kloek, D. M. Heinekey, K. I. Goldberg, Angew. Chem. Int. Ed. 2007, 46, 4736.

[45] T. J. Williams, A. J. M. Caffyn, N. Hazari, P. F. Oblad, J. A. Labinger, J. E. Bercaw, J. Am. Chem. Soc. 2008, 130, 2418. 


\section{Table of contents entry:}

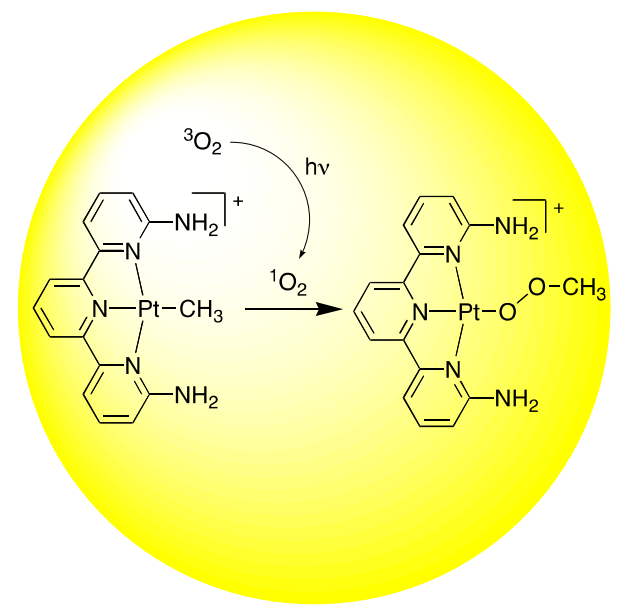

Always look on the bright side: The light-driven insertion of dioxygen into a platinum methyl bond results in a methylperoxo complex which decomposes to formaldehyde and a platinum hydroxo complex. 